\title{
Evaluation of Different Supplementations on Growth and Yield of Elm Oyster (Hypsizygus ulmarius) Mushroom
}

\author{
R.S. Khade, A.C. Jadhav*, M.C. Dhavale and A.P. Gaikwad \\ Department of Plant Pathology and Agricultural Microbiology, College of Agriculture, \\ Pune, Maharashtra State, India \\ *Corresponding author
}

\section{Keywords}

Elm oyster mushroom, Brans, Oilcakes, Flours, Organic supplements, Yield

Article Info

Accepted:

10 October 2019

Available Online:

10 November 2019

\section{A B S T R A C T}

Addition of organic and inorganic supplements to the substrate during cultivation is little known to influence the yield of various species of Elm oyster mushroom. Therefore, an experiment with brans, oilcakes and flours as organic supplements in cultivation of Elm oyster mushroom was undertaken in order to find out better and cheaper supplements to increase the yield of Elm oyster mushroom. The gram flour @ $2 \%$ took minimum incubation period of 17.00 days. Further karanj cake @ 2\% and maize flour @2\% recorded 18 days to complete spawn run and, while the soybean flour@ $2 \%$ took maximum period (21 days) for spawn run. The number of days required for pinhead formation differed significantly and varied between 20.33 to 28.00 days. Similarly, the days required for the first, second and third harvest ranged from 27 to 60.33 days for the total three harvesting. The minimum days of $27.33,41$ and 56.67 were required for first, second and third harvest, respectively after pinhead formation by the treatment of maize flour @ 2\% whereas maximum number of days were required by treatment soybean flour @ 2\% for first and second harvest (34.33 and 50 days) which failed for third harvest. The number of fruiting bodiesper beds varied from 6.11 to 89.56 due to different treatments.The neem cake @ 2\%produced significantly higher number of fruiting bodies per bed (89.56) while the minimum numbers of fruiting bodies were found in the treatment soybean flour @ 2\% had 6.11 fruits / bed. A significant variation in average fruit body weight (2.72 to $10.64 \mathrm{~g}$ per fruit), pileus diameter ( 4.09 to $6.72 \mathrm{~cm}$ ), stipe length $(2.62$ to $4.43 \mathrm{~cm})$ and stipe size $(2.73$ to $3.84 \mathrm{~cm})$ were noted due to different treatments. The observations on yield performance due to different treatments revealed that treatment with neem cake @ $2 \%$ produced maximum yield of mushroom $(841.11 \mathrm{~g} / \mathrm{kg}$ dry) substrate followed by treatment, maize flour @ $2 \%$ with yield of $831.11 \mathrm{~g} / \mathrm{kg}$ dry substrate whereas lowest yield of $320 \mathrm{~g} / \mathrm{kg}$ dry substrate was recorded in treatment soybean flour@ $2 \%$. The investment towards flour and cakes gave an additional returns due to supplementations ranged from Rs. 3.11 to Rs. 18.94 per $\mathrm{kg}$ mushrooms with $\mathrm{B}: \mathrm{C}$ ratio ranging from 0.91 to 2.47 . 


\section{Introduction}

Oyster mushroom is one of the attractive crops successfully cultivated in most developing countries due to its easy cultivation technology. The most amazing point of mushroom cultivation technology is its landless agriculture on useless lignocellulosic agricultural wastes. The oyster mushrooms have potentials to utilize various kinds of waste materials as substrate than any other mushrooms. Addition of the supplements with basal substrate has been as common practice to enhance the yield, nutritional and medicinal values. The present manuscript comprised the detailed information in context of oyster mushroom cultivation, used multiple basal substrates and supplements (additives) as reported in past researches. Therefore, the technology of mushroom agriculture enables us to acquire substrate materials at very low cost or even for free to get biotechnological foods and further led to conserve our environment through efficient bioconversion of wastes with sustainable food security (Ram Naraian et. al. 2016).

Mushroom substrates can supercharged by adding an easily consumed and highly nutritious supplement that the mushroom mycelium can use to grow faster and stronger. Supplementation will also produce larger yields! Be careful though, as too much supplementation can cause higher rates of contamination. Typically, supplementation is achieved by adding bran (oat bran or wheat bran) at a ratio of $5-10 \%$ on dry weight basis. Substrates that are supplemented absolutely need to be fully sterilized or else contaminants will quickly take over. Even after full sterilization, the chance of contamination goes up linearly with the amount of supplementation- and eventually you reach a point of diminishing returns. Elm oyster mushroom cultivation is becoming popular because of its wide adaption to temperature, easily available substrates and simple cultivation techniques, grows on a wide variety of substrates. Its commercial cultivation has been standardized on pasteurized/ sterilized different straws. All year round cultivation can be undertaken. Cereals straws are the most preferred substrate for cultivation of elm oyster mushroom.

\section{Materials and Methods}

The investigations on evaluation of different supplementations on growth and yield of elm oyster (Hypsizygus ulmarius) mushroom was carried out at All India Coordinated Research Project on Mushroom, College of Agriculture, Pune (MS).

The supplements evaluated were wheat bran, rice husk, karanj cake, neem cake, gram flour, soybean flour, maize flour @2\% of wheat straw as substrate for cultivation of elm oyster mushroom. In present study, the pure quality spawn of Hypsizygus ulmarius was obtained from All India Coordinated Research Project on Mushroom, College of Agriculture, Pune (MS).

\section{Substrate preparation and sterilization}

Wheat straw was taken as substrate for cultivation of elm oyster mushroom. Wheat straw was filled in gunny bags and soaked into the solution containing appropriate concentration of formalin and Bavistin chemicals for $16-18 \mathrm{~h}$ in fresh water. After soaking, the excess water was allowed to drain off. The untreated wheat straw was used as control.

\section{Bed filling and spawning}

Spawn prepared on wheat grains was used for spawning @ 2 per cent on wet weight basis of the substrate. Spawning in layers was done in polythene bags of size $35 \times 55 \mathrm{~cm}$. The bags 
were filled with sterilized substrate@ 3 kg per bag and also filled with supplementations @ $2 \%$ per bags. After spawning, the top of polythene bag was tied with thread and about 25 to 30 holes with sterilized pin were made per polythene bag for proper aeration. The spawned bags were then incubated at room temperature for spawn run and observations regarding spawn run were recorded at regular intervals.

\section{Incubation and spawn run}

After bed filling, the beds were kept for incubation at incubation room. Sufficient amount of light, proper ventilation, optimum temperature (i.e. 25 to $28^{\circ} \mathrm{C}$ ) and required humidity (i.e. 70 to $85 \%$ ) were maintained during entire cropping period.

Beds took near about 15 to 22 days for complete spawn run and then transferred to growing room having controlled conditions as that of incubation room.

\section{Cropping}

The bags were cut opened when wheat straw was fully covered with whitish mycelium to expose the substratum surface for initiation of pinheads.

The beds were then kept on racks. The environmental conditions viz., temperature (25 to $27^{\circ} \mathrm{C}$ ), relative humidity (70 to 80 per cent) and diffused light during day time were maintained for primordial formation and fruit body development. Ventilation of 2 to 3 hours per day was given for maintaining $\mathrm{CO}_{2}$ level in the growing room and observations regarding days required for pinhead formation were taken at regular intervals.

Light spray of water was given to beds twice in a day till the end of cropping seasons. Watering was stopped a day before harvesting.

\section{Harvesting}

Fruiting bodies were harvested at full maturity. Mature fruiting bodies were those which started forming spores but the margins of pileus become wavy. The fruiting bodies were harvested when it has curled under edges and well formed gills, because over matured fruit body is fragile and difficult to handle. Harvesting was done by twisting the mushroom fruit body at its base clockwise or anticlockwise. After first harvest, beds were scrapped slightly to remove dead mycelial growth. Then the observations on second and third flushes were taken. Harvested fruiting bodies per bed were collected and fruit body weight was recorded by using electronic balance.

\section{Yield and biological efficiency}

Fresh yield performance of Hypsizygus ulmarius on wheat straw substrate was recorded up to third harvest. The total yield due to different treatments was recorded as $\mathrm{g}$ per kg dry wheat substrate used.

The yield obtained per bed was expressed in terms of biological efficiency (B.E.) and calculated using following formula (Chang and Miles, 1981)

Biological Efficiency (BE \%)

Fresh weight of mushroom

= --------------- x 100

Dry weight of substrate used

\section{Experiment Details}

During present investigation, efficacies of different supplements were evaluated under in vivo conditions. The investigations on evaluation of different supplementations on growth and yield of elm oyster (Hypsizygus ulmarius) mushroom was carried out at All India Coordinated Research Project on 
Mushroom, College of Agriculture, Pune (MS). The supplements evaluated were wheat bran, rice husk, karanj cake, neem cake, gram flour, soybean flour, maize flour @2\% of wheat straw as substrate for cultivation of elm oyster mushroom. The growth parameters viz; days required for spawn run, pin head formation and for first, second and third harvest while the yield parameters (fruit body observations) like pileus diameter, stipe length and size, average fruit body weight, number of fruits $/ \mathrm{kg}$ dry substrate and average yield $/ \mathrm{kg}$ dry substrate were studied in completely Randomized Design (CRD) design with three replications having six bags per treatment.

\section{Results and Discussion}

\section{Days required for completion of spawn run}

The observation on completion of spawn run (Table 1; Fig. 1) indicated that the treatment with gram flour @ 2\% took minimum incubation period of 17.00 days. Further karanj cake @2 \% and maize flour @ $2 \%$ recorded 18 days to complete spawn run and, while the soybean flour @2\% took maximum period (21 days) for spawn run. Singh et al., (1995) and Shah et al., (2004) who also reported that the spawn run in paddy straw inoculated with $P$. florida was completed in 20 to 22 days after spawning and 16.67 days for completion of spawn run respectively on wheat straw.

\section{Days required for pinhead formation}

Number of days required for pinhead formation (Table 1; Fig. 2a and 2b) differed significantly and varied between 20.33 to 28.00 days. The supplementation with rice husk@2\% took minimum days (20.33) for pinhead formation followed by neem cake @ 2\% and maize flour @ 2\% (20.67 days) while maximum days (28.00 days) for pinhead formation were observed in the treatment with soybean flour @ 2\%. Similar trend of results were also reported by Gaikwad (2004) who reported that the time required for pinhead formation varied between 17 to 23 days after spawning in Pleurotus sajor-caju and Sivaprakasam and Ramraj (1991) reported, 25 to 27 days for appearance of pinhead in case of Pleurotus sajor-caju grown on wheat straw.

\section{Days required for harvest of mushroom}

Similarly, the days required for the first, second and third harvest (Table 1; Fig. 3) were recorded, which ranged from 27 to 60.33 days for the total three harvesting.

The minimum days of $27.33,41$ and 56.67 were required for first, second and third harvest, respectively after pinhead formation by the treatment of maize flour @ 2\% followed by treatments rice husk @ 2\% (27, 42.33 and 58.33 days) and karanj cake @ $2 \%(27.67,43$ and 59 days) whereas maximum number of days were required by treatment soybean flour @ 2\% for first and second harvest (34.33 and 50 days) which failed for third harvest. Mshandete and Kivaisi (2013) who reported that the days required for harvesting varied from 42 to 46 . Muhammad et al., (2005) who also reported that time required for harvesting in Pleurotus sajor-caju was 50.7 days on wheat straw.

\section{Number of fruiting bodies per bed}

The results showed that number of fruiting bodies per beds (Table 2; Fig. 4a, 4b \& 5) varied from 6.11 to 89.56 due to different treatments.The treatment with neem cake@ $2 \%$ produced significantly higher number of fruiting bodies per bed (89.56) followed by maize flour @ 2\% that produced 86.67 fruits and karanj cake @ 2\% (85.78 fruits / bed).The minimum numbers of fruiting bodies were found in the treatment soybean flour @ 2\% had 6.11 fruits / bed. 


\section{Average fruit body weight (g)}

A significant variation in average fruit body weight (2.72 to $10.64 \mathrm{~g}$ per fruit) was observed due to supplementation (Table 2). Shukla and Jaitley (2011) who also observed that Pleurotus sajor-caju produced maximum 65 number of fruit bodies per bed and Sharma and Jandaik (1983) who reported that Pleurotus spp. recorded average fruit body weight ranging from 5.0 to $5.8 \mathrm{~g}$.

\section{Morphological characters}

\section{Pileus diameter}

The maximum pileus diameter (Table 3; Fig. $6 \mathrm{a}, 6 \mathrm{~b} \& 6 \mathrm{c})$ was recorded by the treatment Karanj cake @ 2\% (6.72 cm) followed by the treatment Rice husk @ 2\% $(6.55 \mathrm{~cm})$ while the minimum pileus diameter was observed in treatment Soybean flour @ 2\% (4.09 cm).

\section{Stipe length}

The treatment Wheat bran @ 2\%recorded maximum stipe length $(4.43 \mathrm{~cm})$ followed by treatment Neem cake @ 2\%(4.42 cm) while the minimum stipe length was observed in treatment Karanj cake @ 2\% (2.62 cm) (Table $3)$.

\section{Stipe size}

The maximum stipe size $(3.84 \mathrm{~cm})$ was recorded in the treatment Gram flour @ $2 \%$ followed by treatment Karanj cake @ $2 \%(3.77 \mathrm{~cm})$ while the minimum stipe size was observed in treatment Soybean flour@ $2 \%(2.73 \mathrm{~cm})$ (Table 3).

The results (Table 3) revealed that wide variation in morphological parameters like pileus diameter, stipe length and stipe size was observed due to different treatments and ranged from 6.72 to $4.09 \mathrm{~cm}, 4.43$ to $2.62 \mathrm{~cm}$ and 3.84 to $2.73 \mathrm{~cm}$ respectively. The results are comparable with those of Pruthvi et al., (1984) who reported that the mushrooms comprise a large heterogeneous group which differs greatly in their shape, size, colour, appearance and edibility. Hassan et al., (2010) who observed the similar trend of results for Pleurotus ostreatus and Mshandete and Kivaisi (2013) for Pleurotus HK-37.

\section{Yield and biological efficiency}

The observations on yield performance (Table 4; Fig. 7) due to different treatments revealed that treatment with neem cake @ 2\% produced maximum yield of mushroom $(841.11 \mathrm{~g} / \mathrm{kg}$ dry) substrate followed by treatment, maize flour @ 2\% with yield of $831.11 \mathrm{~g} / \mathrm{kg}$ dry substrate whereas lowest yield of $320 \mathrm{~g} / \mathrm{kg}$ dry substrate was recorded in treatment soybean flour@2\%. The neem cake @2\% and 4\% supplementation recorded higher yield of $P$. lorida and $P$. sajor-caju (Anonymous, 2004-05), however, in the present investigation Karanj (Deris indica) cake@ $2 \%$ was at par with control (recommended practice). The experiment conducted under AICRPM at different centres viz., Udaipur, Raipur, Solan, Ranchi, and Pantnagar, reported $2 \%$ of wheat bran beneficial for growing oyster mushroom (Anonymous, 2003-04, Anonymous, 2004-05).

It was revealed that the treatment Neem cake @ 2\% recorded significantly maximum biological efficiency $(84.11 \%)$ over rest of treatments which was found to be at par with treatment Maize flour @ 2\% (83.11\%). The minimum biological efficiency $(32.00 \%$ ) was recorded in treatment Soybean flour@2\%. Biswas et al., (2018) who also reported that chemical treatment (bavistin $75 \mathrm{ppm}+$ formalin $500 \mathrm{ppm}$ ) was found to be most effective among all the treatments and exhibited $120.50 \%$ Biological Efficiency (B.E.). 
Table.1 Effect of different supplements on days required for harvest of elm oyster mushroom

\begin{tabular}{|c|c|c|c|c|c|}
\hline \multirow[t]{2}{*}{ Treatment } & \multicolumn{5}{|c|}{ Days required for } \\
\hline & $\begin{array}{c}\text { Spawn } \\
\text { run }\end{array}$ & $\begin{array}{l}\text { Pinhead } \\
\text { formation }\end{array}$ & $\begin{array}{c}1^{\text {st }} \\
\text { Harvest }\end{array}$ & $\begin{array}{c}2^{\text {nd }} \\
\text { Harvest }\end{array}$ & $\begin{array}{c}3^{\text {rd }} \\
\text { Harvest }\end{array}$ \\
\hline Wheat bran @ 2\% & 20.33 & 21.67 & 27.33 & 44.67 & 57.00 \\
\hline Rice husk@ 2\% & 20.67 & 20.33 & 27.00 & 42.33 & 58.33 \\
\hline Karanj cake @ 2\% & 18.00 & 23.00 & 27.67 & 43.00 & 59.00 \\
\hline Neem cake@ $2 \%$ & 18.67 & 20.67 & 28.33 & 44.00 & 58.00 \\
\hline Gram flour @ 2\% & 17.00 & 27.33 & 29.00 & 45.33 & 60.33 \\
\hline Soybean flour@ 2\% & 21.00 & 28.00 & 34.33 & 50.00 & - \\
\hline Maize flour @ 2\% & 18.00 & 20.67 & 27.33 & 41.00 & 56.67 \\
\hline $\begin{array}{c}\text { Control (recommended } \\
\text { practice) }\end{array}$ & 18.33 & 21.00 & 27.67 & 43.33 & 57.33 \\
\hline SE \pm & 1.23 & 0.85 & 0.99 & 1.38 & 1.22 \\
\hline CD (0.05) & N.S. & 2.60 & 3.04 & 4.22 & 3.74 \\
\hline
\end{tabular}

Table.2 Effect of different supplements on number of fruiting bodies and average fruit body weight $(\mathrm{g})$ of elm oyster mushroom

\begin{tabular}{|c|c|c|}
\hline Treatment & $\begin{array}{c}\text { Number of fruiting } \\
\text { bodies per bed }\end{array}$ & $\begin{array}{c}\text { Average fruit body } \\
\text { weight (g) }\end{array}$ \\
\hline Wheat bran @ 2\% & 78.56 & 8.65 \\
\hline Rice husk @ 2\% & 82.44 & 10.45 \\
\hline Karanj cake @ 2\% & 85.78 & 10.64 \\
\hline Neem cake @ 2\% & 89.56 & 8.35 \\
\hline Gram flour @ 2\% & 72.44 & 8.38 \\
\hline Soybean flour@ 2\% & 6.11 & 2.72 \\
\hline Maize flour @ 2\% & 86.67 & 8.23 \\
\hline Control (recommended practice) & 84.67 & 7.83 \\
\hline SE士 & 9.34 & 0.90 \\
\hline CD $(\mathbf{0 . 0 5})$ & 28.60 & 2.77 \\
\hline
\end{tabular}


Table.3 Effect of different supplements on morphological characters of elm oyster mushroom

\begin{tabular}{|c|c|c|c|}
\hline Treatment & Pileus diameter (cm) & Stipe length (cm) & Stipe size (cm) \\
\hline Wheat bran @ 2\% & 5.64 & 4.43 & 3.49 \\
\hline Rice husk @ 2\% & 6.55 & 3.32 & 3.38 \\
\hline Karanj cake @ 2\% & 6.72 & 2.62 & 3.77 \\
\hline Neem cake @ 2\% & 5.52 & 4.42 & 3.48 \\
\hline Gram flour @ 2\% & 5.57 & 3.99 & 3.84 \\
\hline Soybean flour@ 2\% & 4.09 & 3.92 & 2.73 \\
\hline Maize flour @ 2\% & 5.96 & 3.90 & 3.38 \\
\hline $\begin{array}{c}\text { Control(recommended } \\
\text { practice) }\end{array}$ & 5.77 & 3.73 & 3.19 \\
\hline SE士 & 0.29 & 0.21 & 0.21 \\
\hline CD $(\mathbf{0 . 0 5})$ & 0.89 & 0.64 & N.S. \\
\hline
\end{tabular}

Table.4 Effect of different supplements on yield performance (g/kg substrate) and biological efficiency (\%) of elm oyster mushroom

\begin{tabular}{|c|c|c|}
\hline Treatment & $\begin{array}{c}\text { Total yield (g) } \\
\text { per kg substrate }\end{array}$ & Biological efficiency (\%) \\
\hline Wheat bran @ 2\% & 787.56 & 78.76 \\
\hline Rice husk @ 2\% & 757.78 & 75.78 \\
\hline Karanj cake @ 2\% & 797.71 & 79.77 \\
\hline Neem cake @ 2\% & 841.11 & 84.11 \\
\hline Gram flour @ 2\% & 735.59 & 73.56 \\
\hline Soybean flour @ 2\% & 320.00 & 32.00 \\
\hline Maize flour @ 2\% & 831.11 & 83.11 \\
\hline Control (recommended practice) & 714.78 & 71.48 \\
\hline SE \pm & 55.69 & 5.57 \\
\hline CD (0.05) & 170.55 & 17.05 \\
\hline
\end{tabular}

Table.5 Economics of different supplements in elm oyster mushroom cultivation

\begin{tabular}{|c|c|c|c|c|c|c|}
\hline Treatments & $\begin{array}{c}\text { Yield } \\
\text { (g/kg } \\
\text { substrate) }\end{array}$ & $\begin{array}{c}\text { Gross } \\
\text { monetary } \\
\text { returns } \\
\text { (Rs.) }\end{array}$ & $\begin{array}{c}\text { Investment } \\
\text { (production } \\
\text { cost) } \\
\text { (Rs.) }\end{array}$ & $\begin{array}{c}\text { Net } \\
\text { returns } \\
\text { (Rs.) }\end{array}$ & $\begin{array}{c}\text { Added returns } \\
\text { due to } \\
\text { supplementation } \\
\text { (Rs.) }\end{array}$ & $\begin{array}{c}\text { B:C } \\
\text { ratio }\end{array}$ \\
\hline Wheat bran @ 2\% & 787.56 & 118.13 & 50.21 & 67.92 & 10.91 & 2.35 \\
\hline Rice husk @ 2\% & 757.78 & 113.67 & 49.61 & 64.06 & 6.45 & 2.29 \\
\hline Karanj cake @ 2\% & 797.71 & 119.65 & 50.81 & 68.84 & 12.43 & 2.35 \\
\hline Neem cake @ 2\% & 841.11 & 126.16 & 51.11 & 75.05 & 18.94 & 2.47 \\
\hline Gram flour @ 2\% & 735.59 & 110.33 & 53.61 & 56.72 & 3.11 & 2.05 \\
\hline Soybean flour@ 2\% & 320.00 & 48.00 & 52.31 & -4.31 & -59.22 & 0.91 \\
\hline Maize flour @ 2\% & 831.11 & 124.67 & 50.81 & 73.86 & 17.45 & 2.45 \\
\hline $\begin{array}{c}\text { Control commended } \\
\text { practice) }\end{array}$ & 714.78 & 107.22 & 49.31 & 57.91 & - & 2.17 \\
\hline
\end{tabular}


Fig. 1. Days required for spawn run and pinhead formation

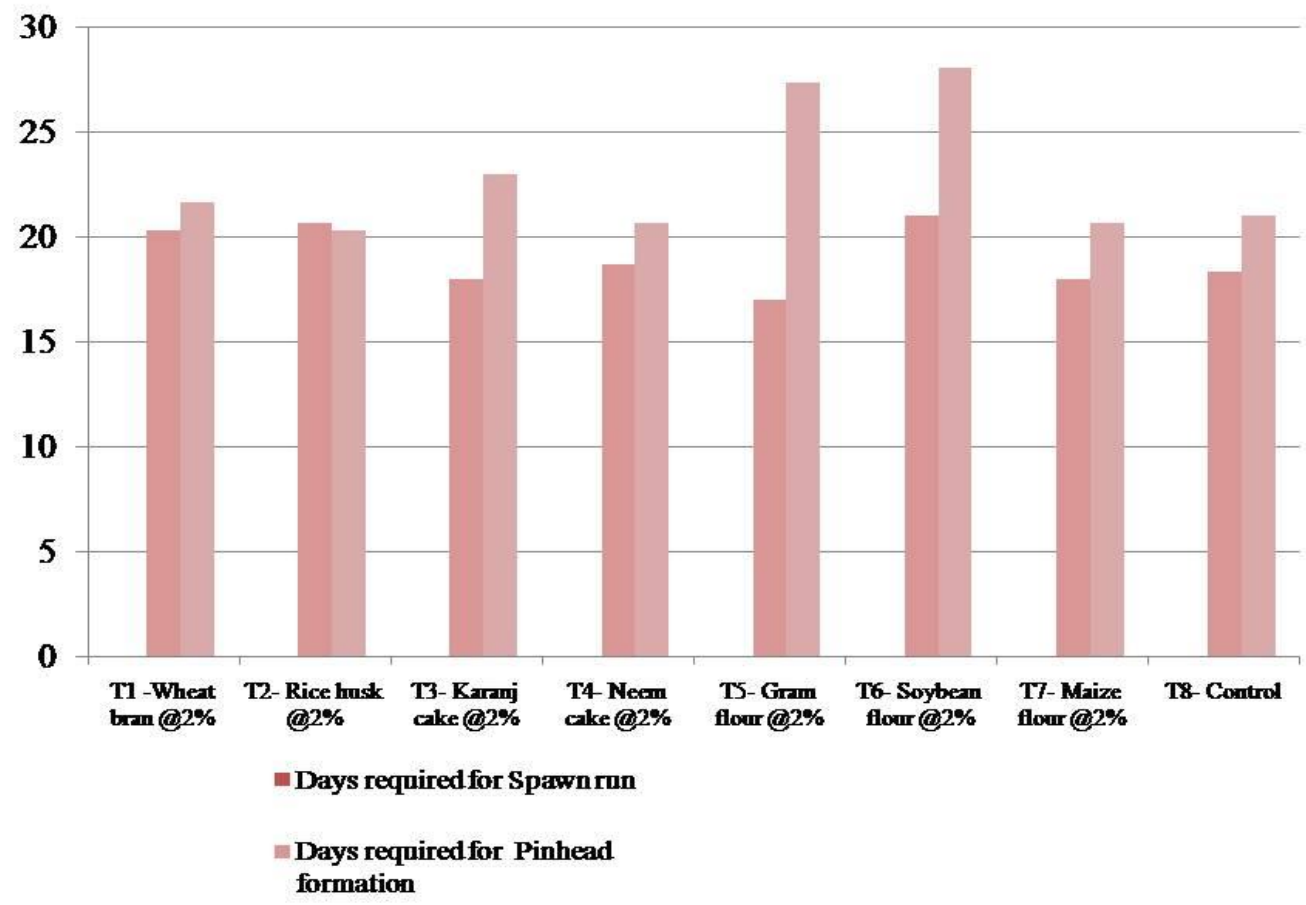

Fig. 2a. Pinhead formation in different treatments

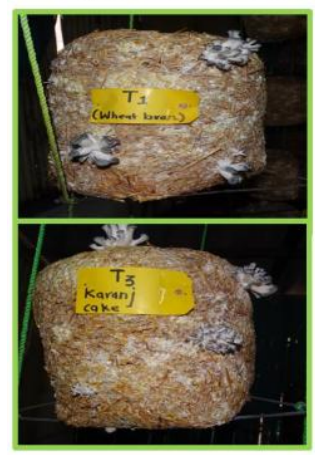

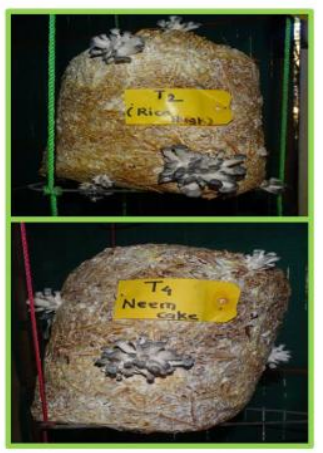

Fig. 2b. Pinhead formation in different treatments

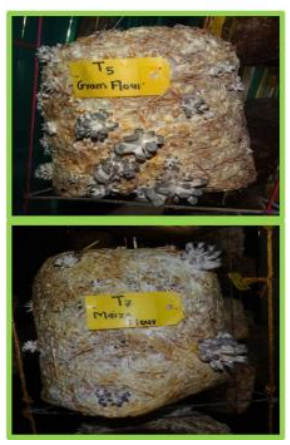

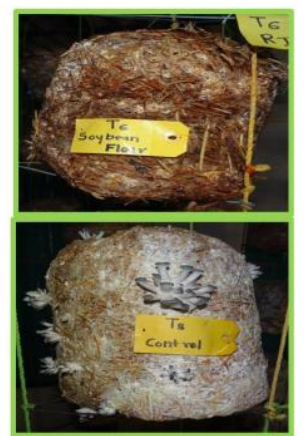

Fig. 3. Days required for harvest of mushroom

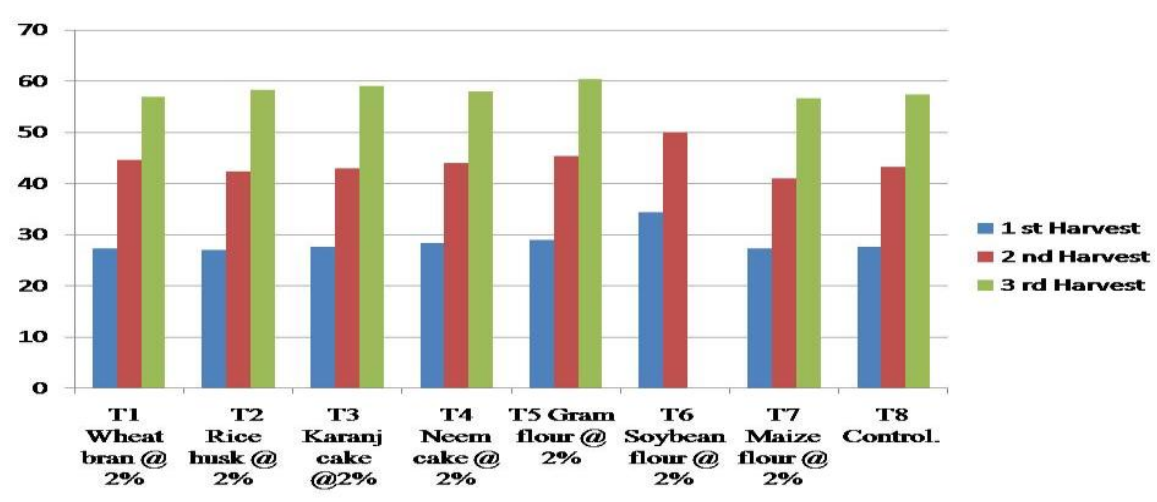


Fig. 4a. Fruiting in different treatments

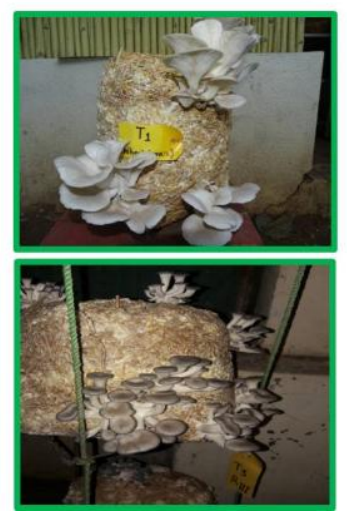

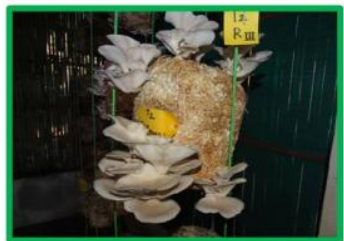

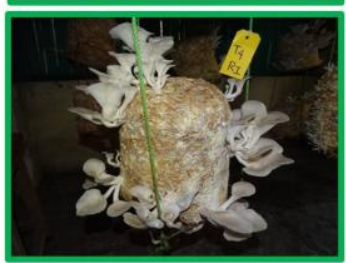

Fig. 4b. Fruiting in different treatments

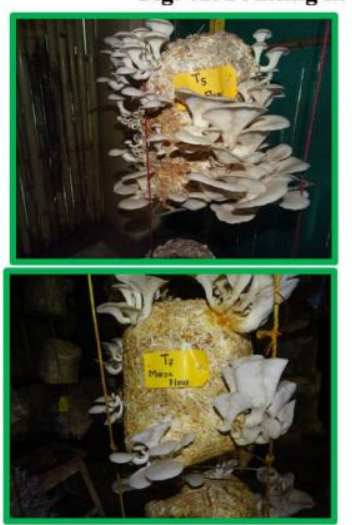

Fig. 5. Number of fruiting bodies and average fruit body weight (g)

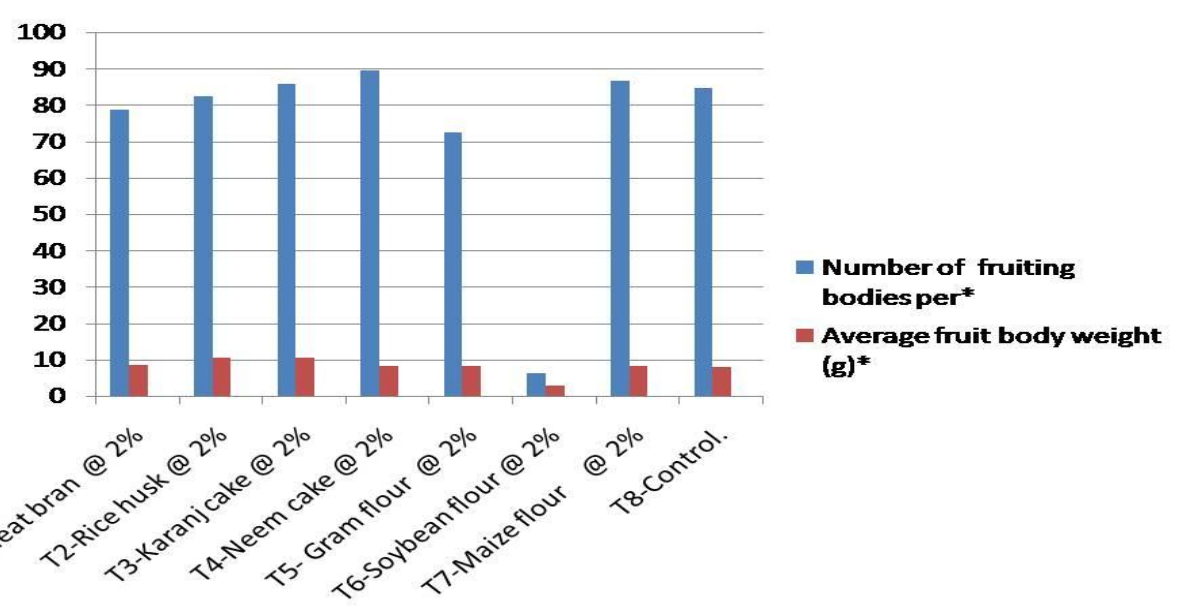

Fig. 6a. Morphological characters

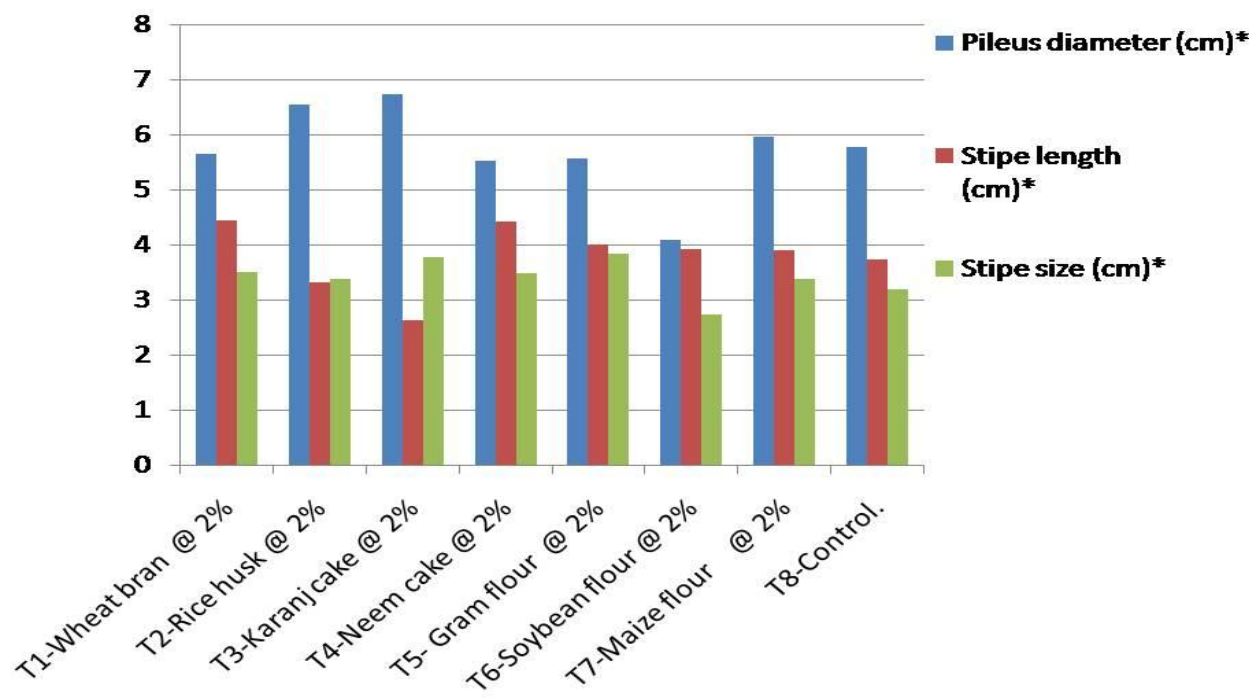


Fig. 6b. Morphological characters
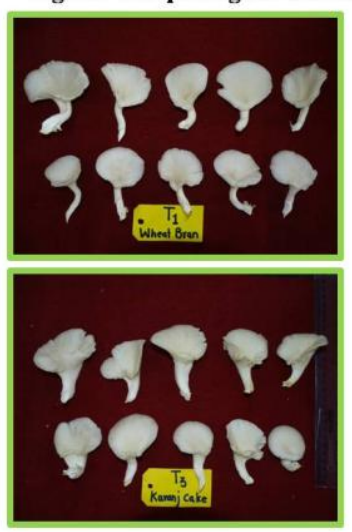
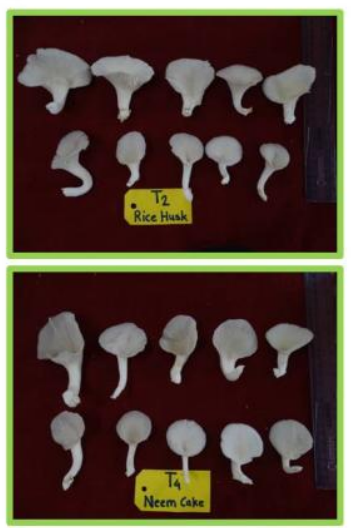

Fig. 6c. Morphological characters

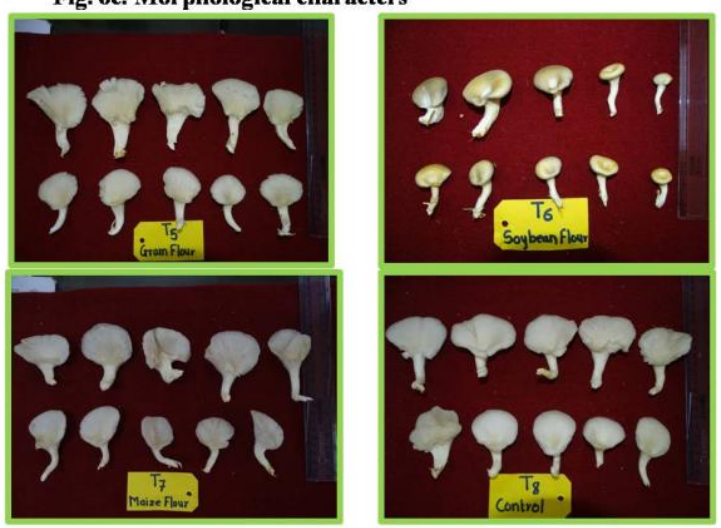

Fig. 7. Yield performance (g/kg substrate) and biological efficiency (\%).
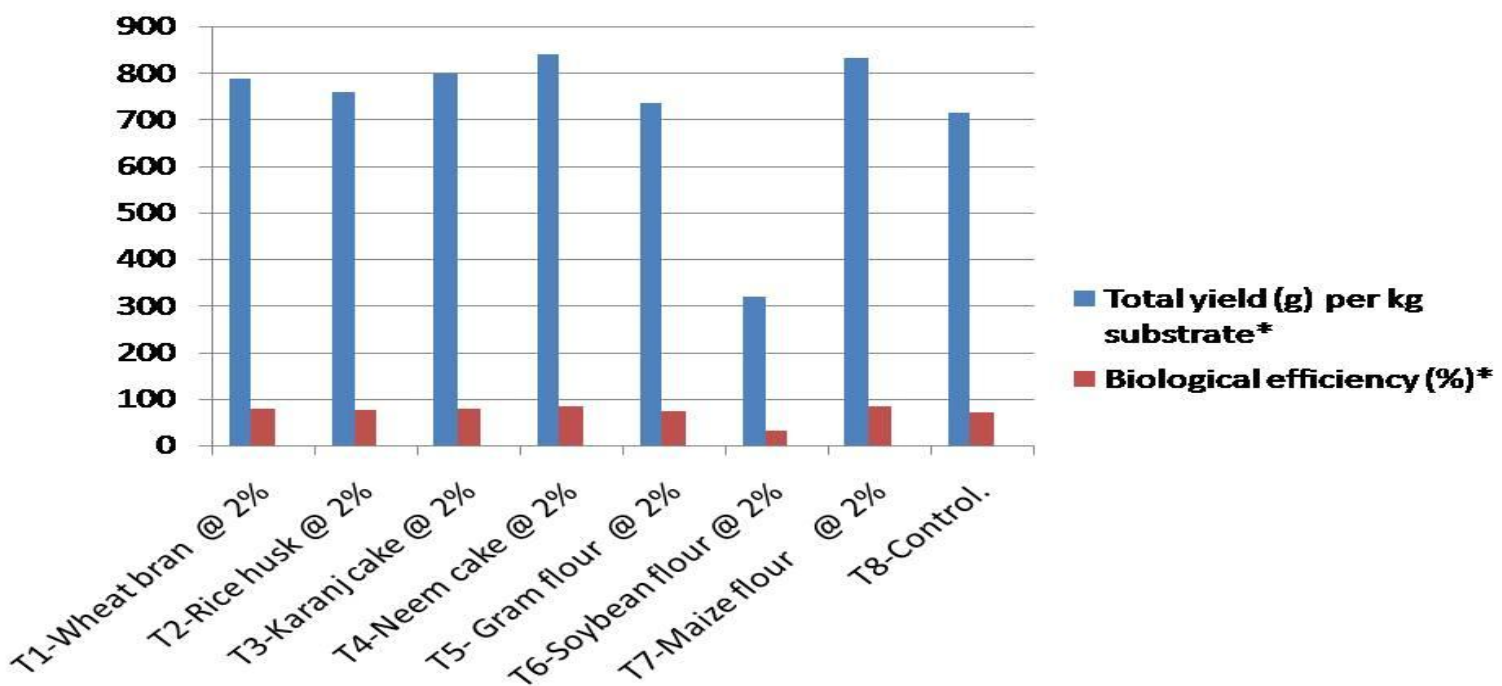

Total yield (g) per $\mathrm{kg}$

substrate*

Biological efficiency (\%)
Hazarika (1998) reported the biological efficiency of organic amendments viz. rice bran $(91 \%)$, wheat bran $(94.25 \%)$, Neem cake $(103.5 \%)$ in paddy straw substrate of Pluerotus sajor-caju.

\section{Economics of different supplements}

The economics of supplementation of wheat substrate (Table 5) with flour and cakes gave more returns over the control (recommended practice) treatment. The investment towards flour and cakes gave an additional returns due to supplementations ranged from Rs. 3.11 to
Rs. 18.94 per $\mathrm{kg}$ mushrooms with $\mathrm{B}: \mathrm{C}$ ratio ranging from 0.91 to 2.47 .

The data showed that the treatment with neem cake@ @ \% recorded maximum added returns (Rs. 18.94/kg mushroom) followed by maize flour @ 2\% (Rs.17.45/kg mushroom), karanj cake@2\% (Rs.12.43) and wheat bran @ 2\% (Rs.10.91).Whereas the treatment with soybean flour @ 2\% recorded negative returns (Rs. -59.22).

Thus, it could be concluded that the supplementation of wheat substrate with neem 
cake@ $2 \%$ was the best for obtaining higher yield and net profit in elm oyster mushroom cultivation.

\section{Acknowledgements}

Authors are thankful to the Mycologist, All India Coordinated Research Project on Mushroom, College of Agriculture, Pune-5 (MS) for providing necessary facilities during the investigations.

\section{References}

Anonymous 2003-04. Annual Report. All India Coordinated Mushroom Improvement Project, NRC on Mushroom, Solan. pp. 21.

Anonymous 2004-05. Annual Report. All India Coordinated Mushroom Improvement Project, NRC on Mushroom, Solan.pp. 19.

Biswas, M.K., Sanjib, K. and Tanmay, G. 2018. EJMP, 22(4): 1-8; Article no. EJMP. 40411.

Chang, S.T. and Miles, P.G. 1981. Edible mushrooms and their cultivation.CRC Press. Boca Raton, Florida. 6: 555565.

Gaikwad, A. B. 2004. Effect of biofertilizers on yield of mushroom (Pleurotus sajor-caju). A M.Sc. (Agri.) thesis submitted to M.P.K.V. Rahuri, Dist. Ahmednagar (MS), India.

Hassan, S., Mohammad, A. and Khan, K. 2010. Cultivation of the oyster mushroom [Pleurotus ostreatus (jacq.) p. Kumm.] in two different agroecological zones of Pakistan. African J. of Biotechnol. Vol. 10(2): 183-188.

Hazarika, D.K. 1998. Effect of substrate and supplements on yield of oyster mushroom (Pleurotus sajor-caju). Mushroom Res. 7(1): 47-48.

Jandaik, C.L. 1989. Response of P. sajor-caju to supplementation prior and after pasteurization of straw. Indian Phytopath. 42: 284-285.

Mshandete, A. M. and Kivaisi, A. K. 2013. Cultivation of oyster mushroom (PleurotusHK-37) on solid sisal waste fractions supplemented with cow dung manure. J. Biology Life Sci. Vol. 4 (1): 273-286.

Muhammad, I., Rauf, A. and Sheikh, M. I. 2005. Yield performance of Oyster mushroom on different substrates. Int. J. of Agric. and Botany.900-903.

Pruthvi, T. S. 1984. Variability in the physiochemical characteristics of spiced papads of Punjab. J. Fd. Sci.Tech.21: 299-301.

Ram Naraian, Singh, M. P. and Siya Ram. 2016. Supplementation of Basal Substrate to Boost up Substrate Strength and Oyster Mushroom Yield: An overview of Substrates and Supplements. International Journal of Current Microbiology and Applied Sciences. Volume 5 Number 5 (2016) pp. 543-553. doi: http://dx.doi. org/10.20546/ijcmas.2016.505.056

Shah, Z. A., Ashraf, M. and Ishtiaq, M.2004.Comparative study on cultivation and yield performance of oyster mushroom on different substrates (wheat straw, leaves, saw dust). Pakistan J. of Nutrition. 3(3): 158-160.

Sharma, A. D. and Jandaik, C.L. 1983. Effect of spawn run duration on yield and some quality parameters of oyster mushroom ( $P$. sajor-caju). Indian $\mathrm{J}$. Mushrooms. IX: 7-11.

Shukla, S. and Jaitley, A. K. 2011.Morphological and biochemical characterization of different oyster mushroom (Pleurotus spp.). J. Phytol. 3(8): 18-20.

Singh, A.K., Awasthi, S.K. and Rai, B. 1995. Utilization of sugarcane trash (dried 
leaves) for production of oyster mushroom Pleurotus florida.

Mushroom Res. 4: 35-38.

Sivaprakasam, K. and Ramraj, B. 1991.
Studies on some factors influencing the yield of oyster mushroom. Indian Mushrooms: Proc. Nat. Symp. Mushroom. Pp. 127-132.

\section{How to cite this article:}

Khade, R.S., A.C. Jadhav, M.C. Dhavale and Gaikwad, A.P. 2019. Evaluation of Different Supplementations on Growth and Yield of Elm Oyster (Hypsizygus ulmarius) Mushroom. Int.J.Curr.Microbiol.App.Sci. 8(11): 1084-1095. doi: https://doi.org/10.20546/ijcmas.2019.811.128 